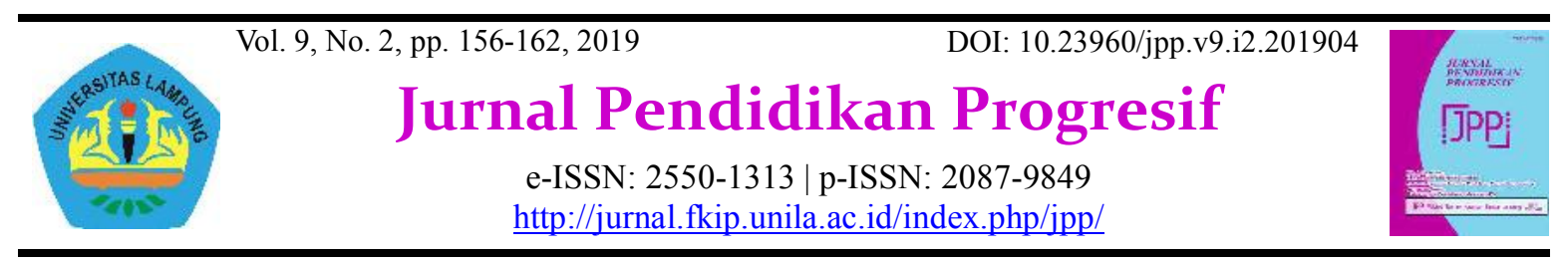

\title{
Identifying Lecturer-Student Interaction and Preference Toward Four English Skills
}

\author{
Suharyanto H. Soro \\ Postgraduate School of Educational Management, Nusantara Islamic University, Indonesia \\ *corresponding e-mail: suharyantosoro@gmail.com
}

Received: 20 June 2019

Accepted: 16 July 2019

Published: 24 October 2019

Abstract: Identifying lecturer-student interaction and preference toward four english skills. Objectives: The aim of this research was to find out the patterns of classroom interaction and preference toward four English skills for students of Islamic Financial Banking Department. Methods: The data collection procedures in the research were based on classroom participant observation, student interviews, and questionnaire. The language that used for student interviews was English, and sometimes combined with Indonesia language. The last instrument was questionnaire used to know the students' preference toward four English skills. Findings: The findings of this research indicated that the classroom interaction can be created through mutual understanding and appriciating between lecturer and student, in form of the manner of lecturer's performance in the classroom, presenting interested and motivated materials, and applying reinforcement. Conclusions: The students' preference toward four English skills indicated that $61 \%$ students liked reading skill very much.

Keywords: Lecturer-student interaction, four english skills, interview.

Abstrak: Mengidentifikasi interaksi dosen-mahasiswa dan kecenderungan terhadap empat keterampilan berbahasa inggris. Tujuan: Penelitian ini bertujuan untuk menemukan pola-pola interaksi dalam kelas dan mengidentifikasi kecenderungan terhadap empat keterampilan berbahasa Inggris bagi mahasiswa jurusan Perbankan Syariah. Metode: Metode pengumpulan data dalam penelitian ini meliputi observasi, wawancara, dan angket. Wawancara menggunakan bahasa Inggris, dan dalam hal tertentu menggunakan bahasa Indonesia. Angket digunakan untuk mengetahui tingkat kecenderungan mahasiswa terhadap empat keterampilan berbahasa Inggris. Temuan: Interaksi dalam kelas dapat tercipta karena adanya saling memahami dan menghargai antara dosen dan mahasiswa, dalam hal ini dosen menampilkan performa yang layak dan meyakinkan dalam menyajikan materi ajar dan memotivasi mahasiswa, serta menerapkan metode reinforcement. Kesimpulan: Kecenderungan mahasiswa terhadap empat keterampilan berbahasa Inggris ditunjukkan dengan 61\% mahasiswa cenderung menyukai keterampilan membaca.

Kata kunci: Interaksi dosen-mahasiswa, empat keterampilan berbahasa inggris, wawancara.

\section{To cite this article:}

Soro, S.H. (2019). Identifying Lecturer-Student Interaction and Preference Toward Four English Skills. Jurnal Pendidikan Progresif, 9(2), 156-162. doi: 10.23960/jpp.v9.i2.201918 


\section{INTRODUCTION}

English is one of compulsory subjects for University students in the initial level. Students are demanded to master and to memorize English words as many as possible in order they can communicate and intract with people from different states. When one talks or mentions the word English language, of course, in our perception it refers to the language used for international communication. We regard that the existence of this language is crucial for the students to develop their carries in the global era. Learning English in the classroom and out of classroom are different (Willis, 2013; Yamanaka, 2006). On the other words, learning English in the classroom involved lecturer and students with formal academic setting (Dagarin, 2004). In this moment, students got English knowledge from their lecturer both theories and practices.

Lecturer and students have different roles in teaching learning processes. Lecturer transferred knowledge and experience to the students, and those knowledge and experince were recieved by the students as a stock for practicing in the real world. Mostly in teaching English, lecturer has a dominant action. Based on research indicated that $78.15 \%$ teacher's talk in the classroom, and $21.16 \%$ for students participation (Semi Sukarni \& Siti Ulfah, 2015). Due to finding above indicated that there was not balance between teacher and student's portion. The same case in the language use that $62 \%$ teacher of English spoke English and 38\% for Indonesia language. Therefore, delivering material teaching in the classroom, mostly teacher of English used Indonesia language than English it self. It is difficult to understand English language wheather spoken or written without having sufficient English vocabulary. That is why, lecturer or teacher of English is suggested to provide English vocabulary for students every English class or meeting (Chen \& Li, 2010; Goldenberg, 2008; Carlo et al., 2004). We know that by practicing English in real interaction, it means that we have applicated the best way to learn English.

In fact, our students lack of English vocabulary. This is one of problems faced by lecturer of English. To create a good interaction in the classroom involves mutual understanding between lecturer and students including the use of English as a means of communication (Pianta, Hamre, \& Allen, 2012; Matsumoto, 2011; Mercer, 2010; Frenzel, Goetz, Lüdtke, Pekrun, \& Sutton, 2009; Gibbons, 2003; Hall \& Walsh, 2002; She \& Fisher, 2002). Sharing and collaborating lecturer with students about the teaching material becomes one of keys to success. In this case, lecturer designed teaching material based on student's needs, namely the use of English in term of Islamic financial banking. So we point out that the lecturer-students interaction that take place in classroom can have an important impact on how students use language and what they ultimate learn.

Most of our students lack of participation in teaching learning process. So that, it is not surprised the students' abilities in English are still not satisfied yet. Even though, they have studied English more than 6 years but they cannot communicate in real life. It happens because of teacher-centered approach doesn't encourage student's participation actively in classroom. The lecturer should present and give real life situation based on students' world in teaching learning process. Brown (1994) claims that the language exposed by teacher should be authentic language and teacher can persuade their students into some peripheral processing by getting them to practice language for meaningful purposes. In order to enhance student's participation and communicative activities, teachers should use authentic materials.

The existence of teacher-students relationship in teaching learning process is very crucial factor. Nugent (2018) on research the Impact of Teacher-Student Interaction on Student Motivation and Achivement stated that teacher- 
student relationships are crucial to student success. It has positive correlation between teacher-student interaction and motivation as well as positive teacher-student interaction and achivement. The key questions asked in this research are as follows: (1) What are the common patterns of interaction that go on in the English foreign language classroom? (2) How can these interactions enhance or inhibit students' communication skills? The objective of the research are: (1) To identify the common patterns of interaction in the English foreign language classroom; (2) To know the factors can enhance or inhibit students' communication skills.

\section{METHOD}

The researcher chose to study lecturer and students in English Foreign Language Interaction at Islamic Financial Banking Department Students of Nusantara Islamic University. The university is a typical private university of slightly less than average university students body size. In the other words, participants in the research were: (a) lecturer of English; (b) the second semester of Islamic Financial Banking Department Students. The number of students is 100 , consists of 38 males and 62 females and come from different state and private schools. The principal goal of this research was to observe how opportunities in gaining communicative ability were enhanced or reduced inside an English foreign language classroom through the categorization of activity types and the analysis of patterns of interaction. To achieve this goal, the researcher used primary instruments, namely: classroom participant observation, student interviews, and questionnaire.

The data collection procedures consist of classroom participant observation, student interviews, and questionnaire. The major interviews consisted of individual interviews and a group interview. The individual interviews were conducted face-to face. Each individual interview lasted between 15 and 20 minutes. The group interview was conducted with the students after the first round of data analysis. A summary of results of the individual interviews was used to elicit the English foreign language interaction. The researcher's interpretations, In addition, followup contact was made with students, either in person or by phone. All research activities were conducted at Nusantara Islamic University academic year 2018-2019.

\section{RESULT AND DISCUSSION}

Teaching is a noun form of "teach" it means that the acitivity is done to transfer knowledge and experience to the students in formal setting or academic setting. This activity covers to build and to develop students cognitive doman, affective doman, and psychomotor doman. Cognitive doman refers to the development of our mental skills and the acquisition of knowledge. Affective domain refers to the area of learning involved in appreciation, interests, and attitudes. The last is domain of psychomotor that related to the creativity skills.

In teaching English, a lecturer does not only teach one skill but also the whole of language skills. These skills are reading, speaking, listening, and writing. Each skill for example, speaking is presented in a lesson interactively. For that reason, the lecturer facilitated and motivated his or her students to dare them for practicing English. By taking a look at the reality of English foreign language classroom, I could find the lecturers in many cases dominate and play directive role in classroom interaction. Their activities in the class are not negotiated in advance, so they just told that "For this meeting, we have starting point from reading comprehension". After that the lecturer had one of students read a short text written using power point on the white board. Then asking the other students about the pronunciation. The question like this "How many mistakes from your 
friend pronunciation?" This is one of conditions makes the learning English language class actively. The following is one of the teaching materials using power point.

Read the following paragraph.

'When I was absent last week. Mr Maha my classmate brought me in all my lecture assigments, and posted my letters for art and design lecturers. And then when my car broke down yesterday he drove me all the way to the campus in the pouring rain ...'

1. How would you describe Mr Maha?

2. Have you ever found the person likes Mr Maha?

To avoid English passive class, a lecturer can do the following steps: call one of students to read an English short text above. After finishing reading a text, a lecturer asked students about the number of pronunciation mistakes. Next having students identify native verb and non native verb. The last asking student's perception about the character's attitudes. Based on my data from student interview indicated that the student can respond the question by calling his or her name.

"Of course I must answer the lecturer's question if mentions my name. I try to give correct answer in English even though I combine with my national language. I think I have in Bahasa Indonesia malu if I cannot answer the question".

Students showed pay attention to lecturer as if understood what lecturer talked about. When asking a question the students sometimes are quite. They were waiting their name called by their lecturer. If he or she can answered the question correctly or responsed to that question, sometimes, lecturer concluded that all students have understood about the material. All students followed and obeyed the rules of learning. They have positive attitudes toward lecturer and keep ethic both in or out of the class. If a lecturer gave a panishment, for example, memorize 30 English words because could not answer the question, he or she done it. Mostly lecturer focused on teaching English theories. This is done of big class and limited time. Lecturer was demanded to have a good performance in teaching English becouse it could affect student's enthusiastic.

"If lecturer no creative, of course lack motivation to join lecture. We want dynamic class to avoid boring"

Based on the data above showed that lecturer has to use contextulized method. Teaching material was designed based on student's interests or English for specific purposes. Based on my classroom observation during one semester was as follows: In the first meeting, they have positive attitudes untill the last meeting. They also heve different seat (separated position) between female and male. The students appriaciated and obeyed the rules of teaching learning process. They are very polite to their lecturer. If the lecturer left the classroom, the students always kiss hand to their lecturer. Every English class, the lecturer gave explanation about the material less than 15 minutes. For example the topic was about bank. The lecturer explained them with different styles based on the situational teaching. The students listened to the explanation seriously. Next, the lecturer asked questions to probe for comprehension, like this:

L: I have explained about the role of Islamic Financial Banking. Any question?

$S: S$ (No one responds)

L: Okay, Do you understand the differences between Islamic and conventional system for banking?

S: C (All students answered it yes)

L: Lecturer asked a question to the one of students to prove his understanding.

L: Question (what is the definition of bank?)

$S: S$ (no response) 
Mostly students could answer the question above using Indonesia language. They have problem if explained it in English language. One of factors was lack of English vocabulary. The answers yes or not were always used for lecturer's question. Even thought it has already explaind about the differences between question "What and Do". I found the students' dare to answer question from their lecturer if that question was asked to all students in the classroom. But it was different self reliant if lecturer asked one by one in front of the classroom. He or she has a reluctant attitude to answer it because afraid of making mistakes.

Interaction could run well because there was a good mutual understanding and appriciating between lecturer and students. Besides that, students' awareness to recieve teaching material taugt by their lecturer. Sometimes, lecturer applied reinforcement system that was to give a present if a student could answer the question correctly. In versa, student made or could not answer the question recieved a punishment. Based on observation indicated that there is a positive correlation with the big or large class and lecturer's control. Big class needs extra time for role play. A lecturer can treat students with variety of role plays, such as write down what his or her lecturer has been said. In the other words, class should be set to be small class, so that a lecturer could control and treat them one by one. The researcher used questionnaire to know or identify the students' interest among four English skills. The respondents to the items of the questionnaire were analyzed in percentage. The explanation of each item was as follows:

The students' opinions toward four English skills that they like best. Most students liked reading skill very much. This was demonstrated by current research by asking subjects to give their preference toward four English skills. From the 100 students as respondents, 11 students (11\%) like listening skill, 20 students (20\%) like speaking skill, 61 students $(61.9 \%)$ like reading skill and the rest liked writing/structure skill. To understand an English text needed prior knowledge. There is an interaction or dialogue between reader and writer, even though it is in form of silence reading. Among four English skills that the easiest to learn, 9 students (9\%) regarded listening skill was easy to learn, 11 students (11\%) regarded speaking skill was easy to learn, 73 students $(73 \%)$ regarded reading skill was easy to learn and 7 students (7\%) regarded writing/structure was easy to learn.

Reading is one of basic needs for students to get information. Lecturer usually gives an English short text to read loudly in the classroom. After reading a text students are expected to find key words or main ideas. More importantly, however, it is now recognized that one text may be read in a variety of style. A student of technique, for example, on seeing a news feature entitled: 'Banking profile', might skim initially to get the general schematic gist and see whether or nor it is interesting or useful. Students' opinion about four English skills that they dislike/hate are as follows 33 students (33\%) dislike listening skill, 9 students (9\%) dislike speaking skill, 1 student (1\%) dislike reading skill and 57 students (57\%) dislike writing/structure. In English hierarchy, listening is the most difficulty skill to learn. Generally, listener infer meaning from what is heard. This will determine expectations about what might come next. As we know that many English word have equal in pronunciation but different meaning. This is one of factors makes students find difficult. The students' need in English teaching learning process are 11 students (11\%) need listening skill, 54 students (54\%) need speaking skill, 10 students (10\%) need reading skill, and 25 students (25\%) Writing/Structure.

Speaking is a heart of language. Mostly lecturer and students spent much time for speaking. On the other words, oral language used dominantly in classroom interaction. Based on the 
observation, student interview, and questionnaire indicated that classroom interaction can be created through mutual understanding and appriciating between lecturer and students, in form of the way of lecturer performance presented materials and applied reinforcement in the classroom. While the student's preference toward four English skills indicated that 61 (61\%) students like reading skill very much.

\section{CONCLUSION}

There was a negative correlation between big class and lecturer's control. It is very hard to apply or focus on English practice. Big class in this context refers to the total of students in a class. That is why, lecturer tended or focused on teaching English theories. To create classroom interaction involved lecturer, students, and teaching materials. Lecturer designed teaching materials in form of task. Because it is regarded as an essential element in the classroom. Task can be different one student and another, depended on the lecturer.

In teaching English, a lecturer does not only teach one skill but also the whole of language skills. These skills are reading, speaking, listening, and writing. Each skill for example, speaking is presented in a lesson interactively. For that reason, the lecturer was suggested to be able to facilitate and motivate his or her students in learning English. This is also a valuable chance for lecturer to improve knowledge in order to evaluate their ability for effective teaching. To avoid English passive class, a lecturer was demanded to have special method, when students were unresponsive and avoid interaction in the classroom. Lecturer can ask a question to one of the students by mentioning his or her name to answer the question.

\section{REFERENCES}

Brown, D. H. (1994). Teaching by principles: An interactive approach to language pedagogy. Prentice Hall Regents; New York.

Carlo, M. S., August, D., McLaughlin, B., Snow, C. E., Dressler, C., Lippman, D. N., .. \& White, C. E. (2004). Closing the gap: Addressing the vocabulary needs of English language learners in bilingual and mainstream classrooms. Reading Research Quarterly, 39(2), 188-215.

Chen, C. M., \& Li, Y. L. (2010). Personalised context-aware ubiquitous learning system for supporting effective English vocabulary learning. Interactive Learning Environments, 18(4), 341364.

Dagarin, M. (2004). Classroom interaction and communication strategies in learning English as a foreign language. ELOPE: English Language Overseas Perspectives and Enquiries, 1(1-2), 127-139.

Frenzel, A. C., Goetz, T., Lüdtke, O., Pekrun, R., \& Sutton, R. E. (2009). Emotional transmission in the classroom: exploring the relationship between teacher and student enjoyment. Journal of educational psychology, 101(3), 705.

Gibbons, P. (2003). Mediating language learning: Teacher interactions with ESL students in a content based classroom. Tesol Quarterly, 37(2), 247-273.

Goldenberg, C. (2008). Teaching english language learners: What the research does- and does not - say. ESED 5234 Master List. 27, Georgia Southern University. Retrieved from: https:// digitalcommons.georgiasouthern.edu/ esed5234-master/27

Hall, J. K., \& Walsh, M. (2002). 10. Teacherstudent interaction and language 
162 | Jurnal Pendidikan Progresif, Vol. 9, No. 2, pp. 156-162, November 2019

learning. Annual Review of Applied Linguistics, 22, 186.

Matsumoto, Y. (2011). Successful ELF communications and implications for ELT: Sequential analysis of ELF pronunciation negotiation strategies. The Modern Language Journal, 95(1), 97-114.

Mercer, N.(2010). The analysis of classroom talk: Methods and methodologies. British journal of educational psychology, 80(1), 1-14.

Nugent, T. (2009). “The Impact Of Teacher-student Interaction On Student Motivation And Achievement". Electronic Theses and Dissertations. 3860. Retrieved from: https:// stars.library.ucf.edu/etd/3860

Pianta, R. C., Hamre, B. K., \& Allen, J. P. (2012). Teacher-studentrelationships and engagement: Conceptualizing, measuring, and improving the capacity of classroom interactions. In Handbook of research on student engagement (pp. 365-386). Springer, Boston, MA.

She, H. C., \& Fisher, D. (2002). Teacher communication behavior and its association with students' cognitive and attitudinal outcomes in science in Taiwan. Journal of Research in Science Teaching: The Official Journal of the National Association for Research in Science Teaching, 39(1), 63-78.

Sukarni, S., \& Ulfah, S. (2015). An Analysis of Teacher and Student Talk in the Classroom Interaction of the Eighth Grade of SMP Negeri 18 Purworejo. Vision: Journal for Language and Foreign Language Learning, 4(2), 261-277.

Willis, J. (2013). Inner and outer: spoken discourse in the language classroom. In Advances in spoken discourse analysis (pp. 168-188). Routledge.

Yamanaka, N. (2006). An evaluation of English textbooks in Japan from the viewpoint of nations in the inner, outer, and expanding circles. JALT journal, 28(1), 57. 